\section{A BCS}

How to cite this article: Lima. ABC

Ophthalmology, 46 years of history. ABCS Health Sci. 2020;45(Suppl.3):e020101.

https://doi.org/10.7322/abcshs.2020S01.1848

Declaration of interest: nothing to declare
This is an open access article distributed under the terms of the Creative Commons Attribution License.

(C) 2020 Lima

\title{
ABC Ophthalmology, 46 years of history
}

\author{
Vagner Loduca Lima ${ }^{1}$ \\ ${ }^{1}$ Head of Ophthalmology, Centro Universitário FMABC - Santo André (SP), Brazil - \\ E-mail:vagner@loduca.com.br
}

The warm deceased holiday of 2018 was cut off by the sad news of the passing of our dear Full Professor of the subject of Ophthalmology, Dr José Ricardo Carvalho Lima Rehder, called by us affectionately as "Professor".

Having left so precociously and unexpectedly, on the eve of completing 35 years in charge of the subject, baffled us. We gathered, "put up the sleeves", established targets, ways, and strategies to keep going.

First step: To look back "If I saw further was for being on the shoulders of giants". Isaac Newton

In the beginning of 2019, following the 50 years of Faculdade de Medicina ABC (FMABC), I went in search of when and how the beautiful and successful history of the discipline of Ophthalmology started in the university.

In 1967 Fundação do ABC was created to support FMABC. The first class has its beginning in 1969, moment in which a lot of other colleges were opened during the military period.

The first Full Professor of the subject of Ophthalmology of FMABC was Prof. Jorge Cavalheiro Willmersdorf Full Professor, egress of Faculdade de Medicina da Universidade de São Paulo (FMUSP), expert in ocular plastic (Figure 1). He stayed in this position for 11 years, between February 1973 to January 1983. After he left, Prof Dr Arnaldo Belletato took over as a regent Professor, also egress from FMUSP, who started his career as a Professor assistant in FMABC together with Prof. Willmersdorf in 1973. He continued as regent between the years of 1983 to 1984 , when, due to health problems, moved away from the coordination of the subject.

If between 1973 and 1984 the subject of Ophthalmology is born and raises respect inside FMABC, in the following phase a new philosophy is implemented, focusing development, growth and future vision.

The career of Professor José Ricardo Rehder (Figure 2) in FMABC has its start in 1975. Egress of Escola Paulista de Medicina (currently UNIFESP), he was hired as auxiliary Professor of the discipline of Histology and

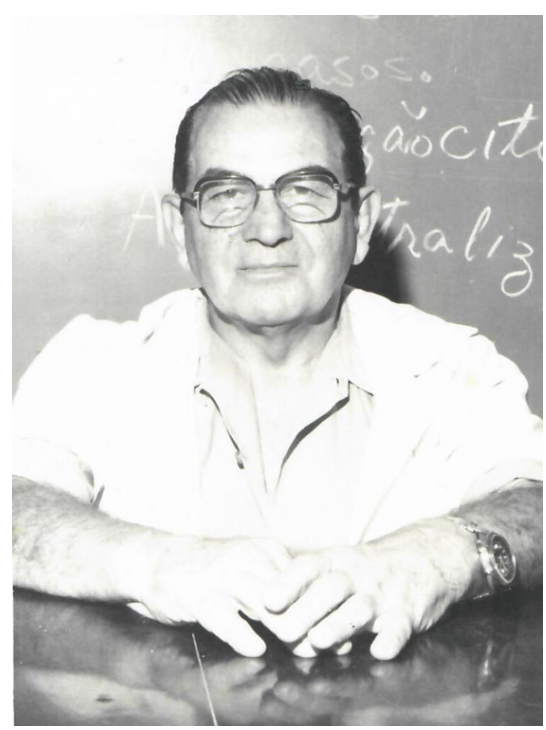

Figure 1: Professor Jorge Cavalheiro Willmersdorf, MD. 


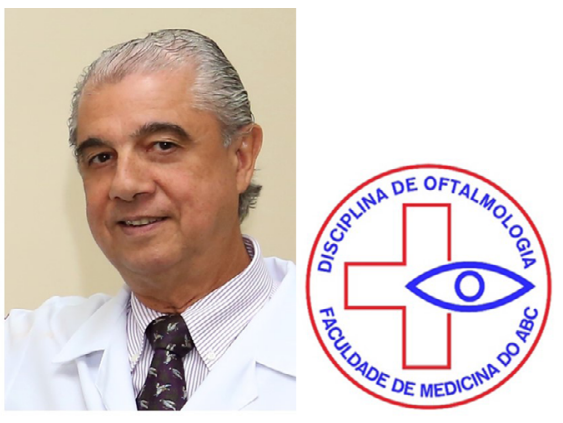

Figure 2 : Professor José Ricardo Carvalho Lima Rehder, MD.

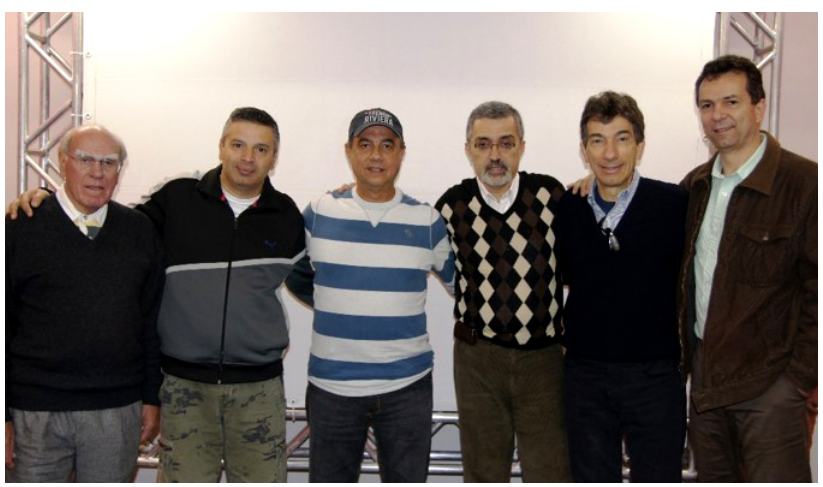

Figure 3: From the left the doctors: José Belmiro de Castro Moreira; Vagner Loduca Lima; José Ricardo Carvalho Lima Rehder; José Lucas de Souza Filho; Walton Nosé; Edmundo Velasco Martinelli.

Morphology, as an invitation from Professor Hisakazu Hayashi. He remained as a Professor of that subject for 10 years, but with the leaving of Prof Belletatto in 1984, and the vacancy of the position in the subject of Ophthalmology, he was invited to take over the position, with the support and incentive of the good friend, and at that time, Full Professor of Escola Paulista de Medicina, Professor Belmiro de Castro Moreira. Rehder was already a Professor at Escola Paulista de Medicina and considered a promising young ophthalmologist.
Professor Jose Ricardo gathered a new team of ophthalmologists to work at FMABC, made by Prof. Walton Nosé, Prof. Lucas de Souza Filho and Prof. Edmundo Velasco Martinelli (Figure 3).

From the difficult start, reduced team, scarce materials, tiny rooms placed in that time in Santa Casa from Santo André up to the current days, a long journey has been covered, but always following very clear and solid guidelines: academic development, concern for the doctor social function, community projects, partnerships with private initiative and public managers and good work environment.

Second step: To establish a strategy and share with the team. "You can't change the wind, but you can adjust the sails". Clarice Lispector

And where are we heading? With the "leaving" of Prof. José Ricardo, and being aware of his references, we set out in search of new challenges keeping the pillars already established.

Yet in 2018, in a general service meeting, it was presented the Teaching Development Program (Programa de Desenvolvimento Docente - PAD/Oftalmologia ABC 2030). With clear targets, implementation deadlines and measurable results, it is proposed that until 2030 strategies of academic development for the whole team of Ophthalmology. The first "Research Day Oftalmo ABC" was created, and once more instituted the prize Prof. José Ricardo Rehder with incentive to research.

In the end, in this special edition of the magazine, we bring part of the results of efforts coming from the last years. These are some of the works from the residents and fellows, while others were sent to master's and doctoral theses.

I wish you all a good reading and I feel very hopeful and really honored to have been helping in the development of this subject in the moment, although all the changes and adaptations needed in the year of 2020 due to the pandemic, the care attending in the ambulatories and emergency rooms kept going, and we were able to increase our lines of research, now incorporating a line focused on the effects of COVID19 in the aspects of Ophthalmology.

Let's move on, the future awaits us. 